\title{
PHONOLOGICAL, MORPHOLOGICAL AND SYNTACTICAL INFLUENCES OF MOTHER TONGUE ON ARAB LEARNERS
}

\author{
Taj Mohammad \\ Department of English, Najran University, K.S.A. \\ E-mail: tajmohd09@gmail.com
}

APA Citation: Mohammad, T. (2015). Phonological, morphological and syntactical influences of mother tongue on Arab learners. English Review, 4(1), 54-65

Published: 01-12-2015

\begin{abstract}
:
Arab learners' mother tongue influence on target language (English) is a very usual and well-known phenomenon in schools and universities. The present study attempts to find and analyze phonological, morphological and syntactical influences of mother tongue on Arab learners. The study aims to critically analyze students' writing samples and focus on the problems like capitalization, punctuation, language use and spelling. It critically diagnoses teachers' perception on the above-mentioned writing problems through a personal interview and offers some recommendations based on the findings through writing samples and interview responses. To achieve these objectives, researcher analyzes forty writing samples of students from first and second midterm examinations at PYP (Preparatory Year Program), Najran University. To the surprise of researcher, writing samples had ridiculous errors. Four writing samples are attached to expose errors of students. Twenty teachers, especially teaching writing at PYP, Najran University, were interviewed in order to investigate the real causes of extremely poor performance of students. Teachers, in the interview, denoted various causes for the present condition of students. They admitted that use of mother in the classroom was one of the major causes of the present condition of students. The study offered some recommendations (based on the findings) like elimination of GT method and implementation of CLT approach in the classroom.

Key words: GT method, mother tongue influences, target language
\end{abstract}

\section{INTRODUCTION}

Arab learners are influenced by mother tongue while studying English language. This problem is more common where English is taught through grammar and translation method. As a result of using GT method, students try to translate every expression in the target language that is almost impossible. It results into various kinds of phonological, morphological and syntactical errors. As Ellis (1997) stated that errors reflect gaps in students' competence. It is so because the student does not know what is correct. Mistakes reflect occasional lapses in performance or slips of tongue (Brown, 2007).

A mistake can be self-corrected, but an error cannot. Errors are systematic, in the sense that they occur recurrently and not accepted by the learner. Hence, only teachers or researchers would trace them, learners would not (Gass and Selinker, 2008; Ellis, 1998). Learners commit errors because there are distinctive differences between Arabic and English in almost all syntactical, morphological, phonological, lexical, semantic, rhetorical and orthographical aspects (Ali, 2007). 
Arabic and English do not share the same linguistic properties. One of the most noticeable differences between the two languages is that Arabic is written from right to left. English, on the other hand, is written from left to right (Sabbah, 2015)

It is very difficult to adopt Arabic as a linguistic model for transfer of learning. Arabic is completely different (phonologically, morphologically and syntactically) from English. According to Jie (as cited in James, 2007), transfer is "the carrying-over of learned responses from one type of situation to another." Transfer can be of two types: positive transfer and negative transfer. The positive transfer refers to the process of using rules from L1, which facilitates or has a positive influence on learning $\mathrm{L} 2$. This transfer is mostly due to similarities between L1 and L2. In contrast, negative transfer is the transfer of rules from L1, which impedes or has harmful influence on the command of rules of $\mathrm{L} 2$. This is due to differences between L1 and L2. (Sabbah S.S., 2015) Because of these linguistic variances, use of GT method often leads to negative transfer. Using mother tongue in the classroom is not a fruitful idea. Moreover, it also inspires students rely more on their mother tongue, Arabic than the target language. Despite rigorous attempts, students are not able even to write a paragraph in the target language, English. Most of their errors in target language denote to capitalization, punctuation, spelling, grammar etc. For the ease of analysis and interpretation of data, this study is divided into four major parts namely capitalization, punctuation, spelling and grammar. This paper attempts to throw light on some of the commonest errors made by Arab learners especially in the four areas. The study thoroughly analyses the writing samples of students and interview teachers with a certain set of questions (based on the major issues of students) to inquire the real causes of errors.

Literature concerning ELT in general is available in a large number, but pragmatic researches conducted on writing are comparatively very few. Some of the researchers have accomplished their research work on identifying the problems of the Arab EFL learners in four language skills like O'Malley. However, Arab learners of English encounter problems in both speaking and writing. This fact has been clearly stated by Haq (1982). For example, Yemeni students learn English in their country where native language is Arabic. A range of overflowing psycholinguistic theories has long mystified foreign language teachers.

Many problems dealing with Arab students have been identified in their course of studying English language. For example, the work of Haq (1982) concluded that most Arab students usually face problems in writing skills. Another study conducted by Zughoul (1984) confirmed the findings of Haq(1982) and revealed that most Jordanian students enrolled in EFL classes have poor oral communication skills, as they usually commit gross lexical errors. They lack proper knowledge of syntax and spelling rules. They also have difficulty in expressing themselves. Most of the studies conducted by Mukattash (1983), Suleiman (1983), and Ibrahim (1983) noted that Arab students' problems in learning English denote to deficiency in English language curricula, alarming teaching methodology and psycholinguistic theories and problems with proper language environments etc. Diab (1996) investigated the interference of Arabic in English writings 
of Lebanese students. The results showed that the transfer of Arabic linguistic structures influenced English writings of Lebanese students on the grammatical, lexical, semantic and syntactic levels.

In his study, Al-Shuaibi (2009) focuses on the phonology of phono tactics, and he finds that learners have difficulty in pronouncing English initial consonant clusters having three members and final consonant clusters of three and four members. He showed some processes involved in the pronunciation of these clusters, namely- reduction, substitution and deletion. Kharma \& Hajjaj (1989) tried to investigate the problems that Arab students of English encounter at the initial stages and showed four major areas of difficulty. First, they found that Arab learners confuse certain pairs of consonant sounds. Second, learners insert a short vowel to break down the long consonant clusters. Third, certain diphthongs are replaced by other sounds due to L1 interference. Last, Arab learners are generally confused with the distinction between certain pairs of vowels.

The belief that L2 should be developed with no reference to L1 is known as language compartmentalization and the reasoning behind this belief is to avoid L1 interference (i.e. errors result from L1 negative transfer) (Cook, 2001).

Macdonald's advice to teachers is "If you get stuck in the middle of a lesson, try to communicate your message by some other means, such as mime or demonstration" (Macdonald, 1993, p. 23).

However, there are researches, which support use of L1 in the classroom. For example, Willis and Willis (2007) consider that L1 cannot be avoided in L2 classrooms since it can bring some benefits to the classroom, especially with beginners. For instance, some teachers have found that learners who did a task in L1 before doing it in L2 showed good progress in L2; moreover, their overall use of L1 decreased.

A similar view is held by

Harbord (1992). He considers L1 a natural communication tool between teachers and students, as in giving class instructions, but he stands firmly against using L1 for explaining grammar. Butzkamm (2003) Supports the previous reasons for employing L1 and adds that L1 promotes learners' dependence on L2.

The advice being "Use as much of the target language as possible, and ensure that use of first language supports the children's language learning" (Cameron, 2001: 199). While reviewing the above research works, it has been observed that most of the researchers have identified problems of Arab EFL learners, but very few have given the remedial measures and solutions for these problems. This study specifically focuses on the pragmatic problems of the four major areas of capitalization, punctuation, language use (grammar) and spelling in writing among the students of writing skills courses at Preparatory Year Program, Najran University. The present research attempts to suggest techniques, methods and elucidation to improve the major problems faced by Arab Saudi learners in general and Najran University in particular. This study also attempts to provide some practical remedies and suggestions for the above mentioned problems.

\section{METHOD}

Fifty students were randomly selected for this study from different writing sections. Their first and second 
midterm examination scripts were selected in order to analyze the writing problems. The teachers, especially teaching writing, were contacted with the samples of writing and interviewed on the causes of errors, which students usually commit. Teachers explained the reasons of students' errors in writing. Students' fifty writing samples from first and second midterm tests were selected randomly. Four of them are presented for this study to examine and to offer the suggestions and relevant remedies to improve the teaching writing instructions and/or to develop the writing skills among learners. During the interview, teachers elaborated the reasons of students' poor performance in writing classes.

\section{RESULTS \& DISCUSSION}

Capitalization

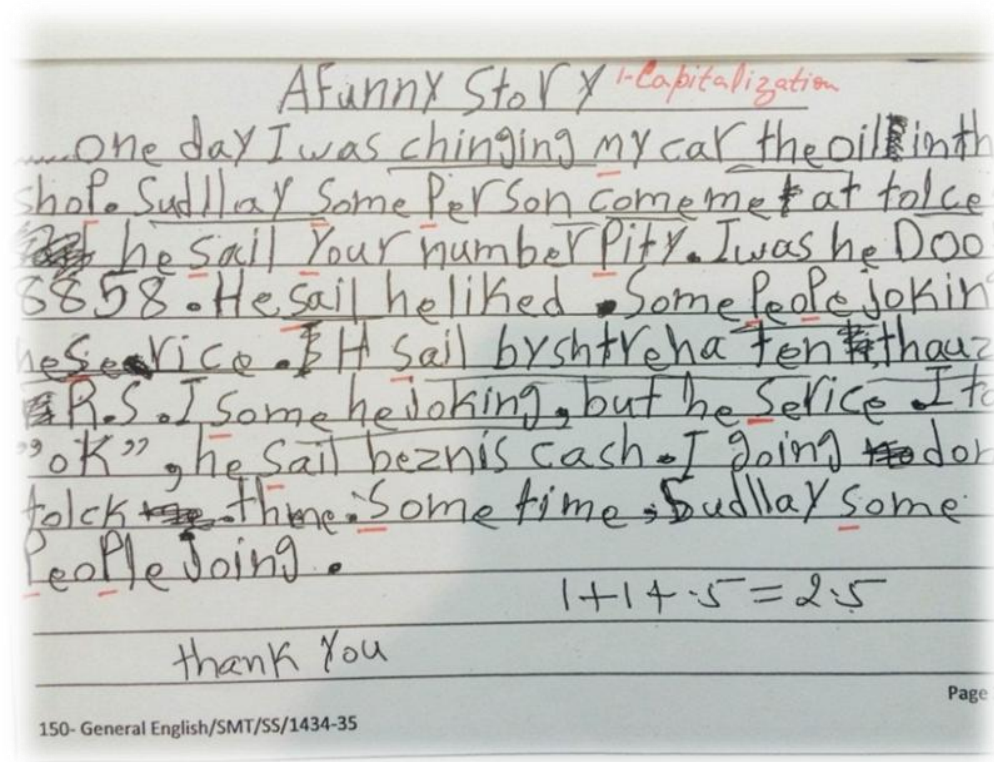

Writing sample 1

There were many samples that the researcher studied though only four of them are presented here with analysis. The researcher has presented a general analysis of the rest of the samples which were not feasible to be pasted here.

As shown in writing sample- 1 , most of the students were confused with capitalization. The student writes pronoun ' $\mathrm{My}^{\prime}$ with a capital letter in the middle of the first sentence of the paragraph. In the same sentence he writes 'shoP' where last letter of the word 'shop' is capitalized. In the second sentence, he writes the common nouns:
'Some' and 'Person' with a capital letter in the middle of a sentence. In the third sentence, he writes verb 'Sail', pronoun 'Your' and adjective 'Pity' with a capital letter. They did not know that a new sentence must begin with a capital letter. In sentence 5, he again writes verb 'Sail' with a capital letter. In sentence 6 , he misspells the noun 'PeoPe' for people and writes ' $\mathrm{P}$ ' in capital letter. In the same sentence, he writes the noun 'Service' with a capital letter. Then again in sentence 7, he writes 'Sail' with a capital letter. In sentence 8, he writes 'Some' and 'Service' with a capital letter. 
Taj Mohammad

Phonological, Morphological and Syntactical Influences of Mother Tongue on Arab Learners

Again in Sentence 9, he writes 'Sail' with a capital letter. In the last sentence, the student again writes 'Some' with a capital letter. In the same sentence, he writes 'PeoPle' with capital ' $\mathrm{P}$ '.

It shows they are confused while capitalizing the letters. They are unaware of the rule that proper noun is to be written with a capital letter and common noun needs not be capitalized.

Sometimes, students use verb with a capital letter like Sail. It is because of the influence of their mother tongue, they try to translate each and everything including capitalization and spelling too.
There is no capital letter in Arabic. In Arabic, sentences do not start with capital letter. As influenced by mother tongue, they do not write proper noun and personal pronouns with capital letters. For example, means ' $\mathrm{He}^{\prime}$. They write 'he' with small letter, no matter middle or start. The same is the case even with proper noun for example, السعودية. They get confused with al that means 'the'. They write in English it with 'the saudi arabia'. It happens so because they confuse al with definite article 'the'. Students do not capitalize proper nouns.

\section{Punctuation}

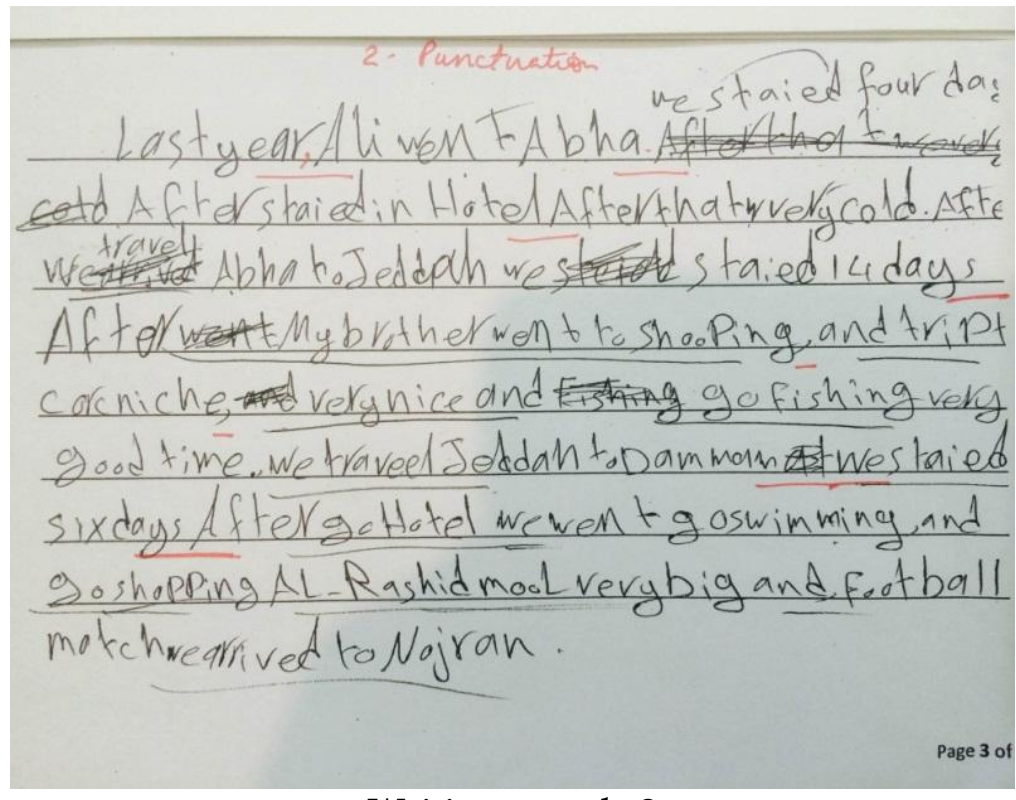

Writing sample 2

As shown in writing sample-2, at the end of sentence 2 , no (.) is used. Sentence 3 is confusing. At the end of sentence 4, no (.) is used. In sentence 5 , commas are not used at their proper places. At the end of sentence 6, no full stop is used. At the end of sentence 7, no full stop is used. Sentence 8 is obscure and commas are not used at proper places.

$$
\text { هو يقرا الكتاب، المجلات،الجرائد. }
$$

Punctuation is found in Arabic, but it is a little bit different from English. There is Full stop (.) in Arabic. For هو يقرا الكتاب. . Example, He reads a book This is the reason that most of the students do not make mistakes in (.). Comma (,) is there but its position in Arabic is different from English. For Example, 'He reads book, magazines, newspapers etc'. 
Colon (:) has the same position in Arabic too. That is why students do not make mistakes in this area. For example, 10:9 من الساعة

Semicolon (;) is the same in Arabic. So students hardly make mistakes in semicolon. Question mark (?) is also the same in Arabic. For example, ماذا تريد?
Inverted commas are also put at the same place in Arabic. For example, قال عادل"اريد ان اذاكر الدرس".

Another problem is that Arabic is written from right to left but English is vice versa. Students are organized to write from right to left. Therefore, there are organizational differences between Arabic and English which result into serious mistakes so often.

\section{Language use}

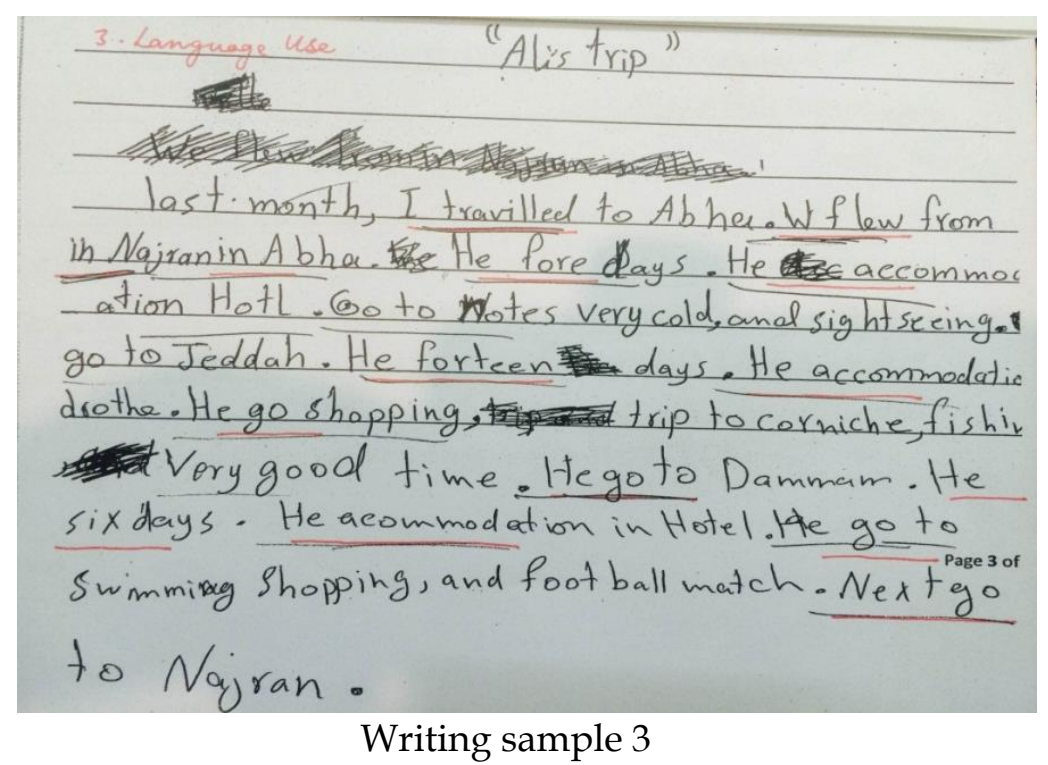

As shown in writing sample-3, student misspelled the verb 'travilled'. In sentence 2 , student was not able to write pronoun 'we' and preposition 'in' properly. In sentence 3, helping verb was not used. In sentence 4 , no verb is used. Sentence 5 is obscure. In sentence 6 again, helping verb is not used. In sentence 7 , no verb is used. In sentence 8 , proper form of verb 'go' is not used. In sentence 9, no verb is used. In sentence 10 , no verb is used. In sentence 11 , no proper form of verb according to tense is used. In the last sentence 12, no subject is used. The form of verb ' $\mathrm{go}^{\prime}$ ' is also misused.

The major problem that students face is that there is no helping verb in
Arabic. That is why students hardly use any helping verb in their sentences. For example, they commonly make mistakes in continuous tense, perfect tense, passive voice etc. There is no present perfect tense in Arabic. Therefore, students are more prone to commit these sorts of mistakes. Another important aspect is that students are always confused with singular and plural. They treat plural of English as singular. For example, 'The boys was in class'.

In English, there is no masculine and feminine when demonstrative pronouns are used. For example, 'This is a cat'. Here you don't know if the cat is لا تعرف هو يقصد (هذا قط) ام (هذه (He or She) قطة). 
In Arabic, one can change from masculine to feminine or vice versa by changing one letter in the word.

(هو يكتب - هى تكتب)

Normally sentences start with a verb in Arabic. The sentence structure in Arabic is Verb+sub+object. For example, 'yaqra aldas' means 'He reads the lesson'. Verb changes according to doer. It is different with 'he' or 'she'. They are called verbal clause. (jumla failiya)

$$
\text { تقر ا الدرس }
$$

Jumla ismiya (noun clause) starts with subject, for example, Adil plays football.عادل يلعب الكرة. Here the structure is subject +verb+ object. There are two ways of writing a sentence; verbal or noun clause. Usually, sentence starts with verb. If name of the doer is given, it can start either way. For example, Adil plays football. (بلعب عادل الكرة) while in

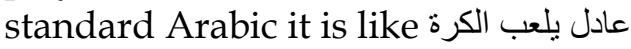

There is no auxiliary verb in Arabic. For example, Adil is playing football. (الانعادل يلعب الكرة) Here adverb decides the tense that denotes continuous but there is no auxiliary verb. These kinds of structures confuse the learners. Students influenced by their mother tongue are likely to commit mistakes with these kinds of structures.

Arabic has model verbs too like 'will'. For example (عادل سوف يلعب الكرة) Adil will play football. 'Sawf+verb' ( سوف هill play'. 'May' in Arabic is called (He may play يجب. football'. 'Must' in Arabic is called for example, يجب ان اذاكر الدرس 'means 'he must study the lesson'. Like English, in Arabic too, model comes before the verb. That is why students do not make mistakes regarding models in English.

Arabic doesn't have present perfect, past perfect, present perfect continuous and past perfect continuous.
It has only Indefinite and continuous which are written with a little difference in Arabic. For example,

Adil plays football.

(Present Indefinite) Adil is playing the football. (Present Continuous)

Here are some examples from the Past tense too. For example, Adil played the football yesterday. (Past Indefinite) Adil was playing the football yesterday. (Past Continuous)

Kana (كان) is adverb here. Here, for auxiliary verb, كان is used and that is adverb of time referring to past. الان (now) is also adverb that denotes to present. So, in Arabic, there is no auxiliary verb but adverbs are used in the sense of expressing past or past to denote auxiliary verbs. There is a lot of difference between the sentence structure of Arabic and English. That is why students who try to translate each and everything in English commit serious errors.

In future tense too, adverbs denote the auxiliary verb expressing the future. For example,

Adil will play football tomorrow. (Future Indefinite) عادل سوف يكون يلعب الكرة غدا Adil will be playing football. (Future Continuous) is adverbial phrase that denotes 'will be'. No future perfect or future perfect continuous tenses are there in Arabic language. Students have difficult time in understanding perfect and perfect continuous tense sentences. As far as articles are concerned, there are definite and indefinite articles in Arabic language. For example: الجامعة جامعة means 'the university' and 
'university' (any university). So it is an indefinite article. But there is no ' $a$ ' and 'an'. Because of a very common use of 'al' in Arabic, students often use 'the' even if there is no need of definite article in English structure.

Prepositions are also found in Arabic. For example,
الكتاب على المنضدة.The book is on the table سلى means on. 'Under' is denoted by تحتى For example, الكتاب تحت المنضدة

'The book is under the table'. 'In' means الىى For example,

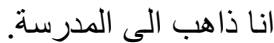

Students, usually, do not make mistakes in prepositions because there is a wide use of prepositions in Arabic.

Spelling

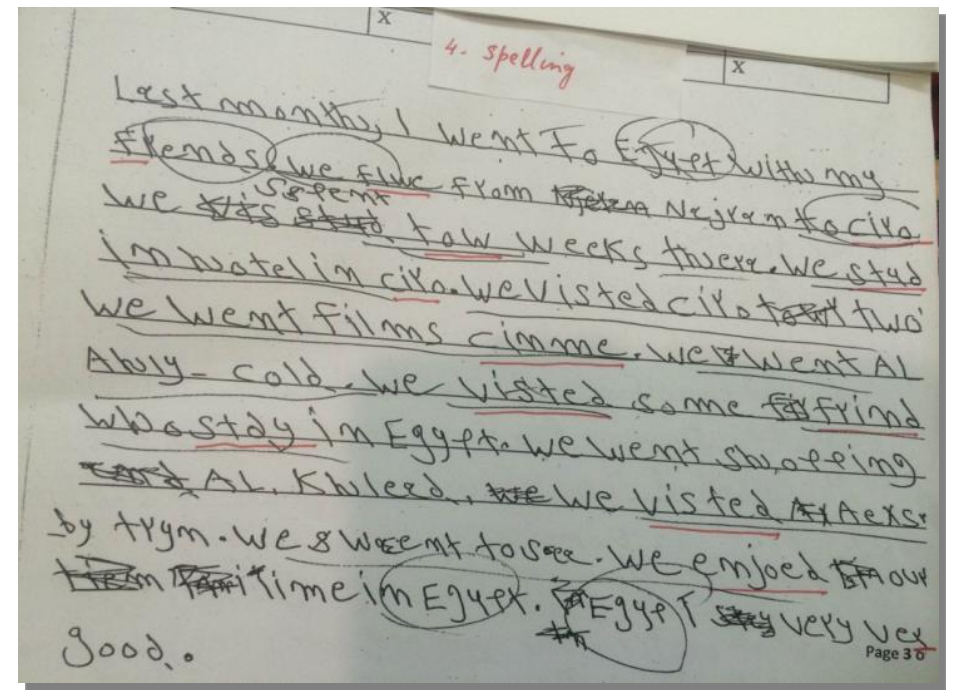

Writing sample 4

As shown in writing sample-4, most of the students have problems in spelling. In sentence 1 of the paragraph, students misspelled the noun 'friends'. In the second sentence, he misspelled the verb 'flwe' and noun 'Ciro'. In the third sentence he misspelled adverb of number 'tow'. In sentence 4 , he misspelled the verb 'stud' and 'ciro' in the same sentence. In sentence 5, he misspelled the noun 'cinme'. In sentence 7 , he misspelled the verbs 'visted', 'stdy' and noun 'frind'. In sentence 9 he repeated the same mistake 'visted'. In sentence 11 , he misspelled the verb 'enjoed'.
Students commit serious mistakes in spelling as shown above. Spelling is very much influenced by phonetic transcription. Students listen to an English word and then try to spell it as they listen to it. For example, there is no $P$ sound in Arabic. They write $B$ for $P$. They write 'pepsi' as 'bebsi'. P can be pronounced only in cluster sounds like 'Th' and 'za.

That is why most of the spelling mistakes are due to phonic transcription. English words are complex in writing and pronunciation as well. For example, International if written according to pronunciation will be Intarnashonal. In Arabic, there are fixed rules of writing 
Taj Mohammad

Phonological, Morphological and Syntactical Influences of Mother Tongue on Arab Learners

coping with pronunciation without any difference.

One problem with English consonants is the distinction between the voiceless post alveolar fricative and the voiceless post alveolar affricate, namely 'sh' and 'ch' respectively. Since Standard Arabic does not treat the distinction as phonemic, Arab English learners confuse 'catsh' for 'catch'.

Equally confusing to Arab speakers of English is the distinction between vowels. Since Arabic has only long and short versions of three vowel phonemes, the distinction between $\mathrm{e}, \mathrm{i}$, ee, $y$, and ai as in 'Turkee', 'italya', and 'palestain' is extremely challenging to Arabs who tend to mispronounce and consequently misspell words with these vowels.

A similar peculiarity of each is the spelling of the / $f /$ sound. Is it spelt as ' $\mathrm{f}$ ', ' $\mathrm{ph}$ ', or ' $\mathrm{gh}$ '? Arab learners struggle with the spelling of this sound and the phonemic voicing contrast between / $f$ / and $/ \mathrm{v} /$ since the voiced version is not a phoneme in Arabic; hence, these spelling errors: 'selfestor stalon' for 'Silvester Stallone' are very common.

Analysis and Discussion on Interview

Another method used to collect the data was interview method. Twenty samples were selected out of 30 which were filled in with complete information. The participants responded to the following questions in the interview: 1. Some major causes for poor performance in capitalization: 2. Some major causes for poor performance in punctuation:

3. Some major causes for poor performance in language use: 4. Some major causes for poor performance in spelling:

Table-1: Results and discussion on Interview Question no. 1

\begin{tabular}{lll}
\hline $\begin{array}{l}\text { Q.1. } \\
\text { participants }\end{array}$ & Some major causes for poor performance in capitalization: \\
\hline 5 & $\begin{array}{l}\text { Students lacked motivation. } \\
\text { Impractical writing activities. }\end{array}$ \\
\hline 6 & $\begin{array}{l}\text { Most of the students had poor background in writing. } \\
\text { Students were reticent to write in target language. } \\
\text { Limited vocabulary. }\end{array}$ \\
\hline 5 & $\begin{array}{l}\text { Writing exercises were not as practical as they should be. } \\
\text { Students were not exposed to writing at an early stage. }\end{array}$ \\
\hline 4 & $\begin{array}{l}\text { Most of the students were unable to understand what is proper noun and how to } \\
\text { capitalize it } \\
\text { Students faced difficulties in understanding how to start a new sentence } \\
\text { Students didn't distinguish among nouns, verbs, pronouns etc. }\end{array}$ \\
\end{tabular}

As shown in Table 1 , in response to question number 1 , most of teachers admitted that students had a poor background in writing because there was not much emphasis on writing in their schools. They hesitate to write in target language. They also have limited vocabulary. All these factors often lead students to commit grave mistakes.

Table-2: Results and discussion on Interview Question no. 2

\begin{tabular}{lll}
\hline Q.2 & Number of participants & Some major causes for poor performance in punctuation: \\
\hline 5 & $\begin{array}{l}\text { Students did not get an opportunity to practice punctuation in } \\
\text { the classroom } \\
\end{array}$ \\
& Students didn't pay much attention on punctuation \\
\hline
\end{tabular}




\begin{tabular}{ll}
\hline & $\begin{array}{l}\text { In early schools, students didn't have much exposure to } \\
\text { punctuation }\end{array}$ \\
\hline 8 & $\begin{array}{l}\text { Students compare punctuation with Arabic, their mother tongue } \\
\text { Students were taught through GT method in their earlier classes } \\
\text { that influenced their learning of punctuation }\end{array}$ \\
\hline $\begin{array}{l}\text { Some students do not know English at all and teachers do not } \\
\text { know Arabic at all. It often results into lack of communication. } \\
\text { Sometimes students do not understand the technicality of } \\
\text { punctuation because they cannot understand English teachers as } \\
\text { their English is too poor }\end{array}$ \\
\hline
\end{tabular}

As shown in Table 2, in response to question number 2 , there were some common difficulties faced by the students. Teachers admitted that students compare English punctuation with Arabic one as mother tongue influenced their writing practice. Some bilingual teachers also used GT method in classes, which caused the problem to its severity. Arabic had a great influence on them while writing English language. Because of the bilingual approach, students often commit serious mistakes.

Table-3: Results and discussion on Interview Question no. 3

\begin{tabular}{lll}
\hline Q.3. & Number of participants & Some major causes for poor performance in language use: \\
\hline 05 & Students are often confused with tenses \\
\hline 15 & $\begin{array}{l}\text { GT method is a big obstacle because Arabic and English are } \\
\text { two completely different languages on the basis of structure } \\
\text { and grammar }\end{array}$ \\
\hline
\end{tabular}

As shown in Table 3 , in response to question number 3, 5 teachers completely agreed that the students were confused with tenses. The rest of fifteen teachers accepted that bilingual method of teaching is a big problem. They translated each and everything from Arabic to English and vice versa. Translation practices often lead to serious mistakes in target language.

Table-4: Results and discussion on Interview Question no. 4

\begin{tabular}{lll}
\hline Q.4 & Number of participants & Some major causes for poor performance in spelling: \\
\hline 6 & $\begin{array}{l}\text { Students have no knowledge of English phonetics. They cannot } \\
\text { speak certain sounds like 'p' and 't'. It often leads to spelling } \\
\text { errors. } \\
\text { Textbook does not have enough space to practice the spelling } \\
\text { of words }\end{array}$ \\
\hline 5 & Spelling games are not provided in the textbook \\
\hline 5 & Students are not motivated to improve their spelling \\
\hline 4 & $\begin{array}{l}\text { In early classes, students were not exposed to rigorous practice } \\
\text { of spelling }\end{array}$ \\
\hline
\end{tabular}

As shown in Table 4, in response to question number 4 , there were some common causes of poor performance of students in spelling. The most common causes were no knowledge of phonetics, confusing sounds, textbook lacking activities to improve spelling. Writing is only considered as a part of formal courses. Sometimes it is boring for students. As they do not enjoy writing, they hardly pay attention to spelling. 
Taj Mohammad

Phonological, Morphological and Syntactical Influences of Mother Tongue on Arab Learners

Their only aim is to get pass marks in the examination.

\section{CONCLUSION}

The analysis of students' ability to capitalize sentences shows they are confused while capitalizing the letters (See writing sample-1). Arabic language does not capitalize starting of a sentence, proper noun etc. Students' dependence on mother tongue often results into negative transfer and sample one is a good representation of it. Therefore, it is recommended that use of mother tongue should be completely banned not only in the university but also in schools.

Punctuation is found in Arabic, but it is a little bit different from English. Students, as influenced by Arabic punctuation, often commit errors in punctuation (See writing sample-2). These errors also attribute to excess use of mother tongue in the classroom. Therefore, punctuation can be improved with the help of practice exercises. Teachers can also assess progress of students by conducting quizzes and class tests from time to time.

The analysis of students' ability to use language and grammar shows that they have many problems in expressing ideas even if they are given controlled writing paragraph (See writing sample3). As interview with teachers demonstrate that GT method is a major cause of these errors. Students should be discouraged to think in Arabic and then translate into English. Teachers can use direct method or communicative language teaching approach as it is the best solution to tackle this problem.

In case of spelling, the analysis of writing samples shows that there are many errors (See writing sample-4). For example, students are usually confused with ' $p$ ' and ' $b$ ' as ' $p$ ' sound is not found in Arabic alphabet. Teachers also accepted it one of the major causes of spelling mistakes during the interview. This confusion, as teachers opined, often leads to spelling errors. Cook (1999) suggests that the most common spelling errors are related to pronunciation and this is shown through substituted vowels and phonological mistakes. Bebout (1985) is of the opinion that foreign speakers' mispronunciation of English is a recognized cause of spelling errors. These kinds of spelling problems which Arabic speakers have are discussed in more details in Swan \& Smith (1987) and Kharma \& Hajjaj (1989). The former, for example, highlights problems Arabic learners of English have with the 'mirror' shaped letters(e.g. p and q) and comment on the difficulties which stem from the fact that Arabic is written from right to left (thus learners may write crwon rather than crown). This reveals that either students are not aware of these sorts of mistakes or their attention is never invited to it. This can be attributed to the lack of background knowledge of the students in foreign language. Students should be exposed to phonetics. Teachers must practice phonemic transcription in the class to avoid spelling errors.

\section{REFERENCES}

Haq, A. F. (1982). An analysis of syntactic errors in the composition of Jordanian secondary students" Unpublished MA Thesis. Yarmouk: Yarmouk University.

Ali, N. (2007). Some linguistic problems facing Arab learners of English. Adab Alrafidayn. (48), pp 1-14, Retrieved from http:/ / www.iasj.net/iasj?func=fulltext\&aI $\mathrm{d}=33586$

Bebout, L. J. (1985). An error analysis of misspellings made by learners of English as a first and as a second language. Journal of Psycholinguistic Research 14, 569-593 http:/ / dx.doi.org/10.1007/BF01067386

Brown, D. (2007). Principles of language learning and teaching (fifth edition). London: Pearson Longman. 
ENGLISH REVIEW: Journal of English Education Vol. 4, Issue 1, December 2015
ISSN 2301-7554

https://journal.uniku.ac.id/index.php/ERJEE
Butzkamm, W. (2003). We only learn language once: The role of the mother tongue in EFL classrooms: death of a dogma. Language Learning Journal, 28, 29-39. http:/ /dx.doi.org/10.1080/0957173038520 0181

Cameron, L., 2001. Teaching languages to young learners. Cambridge: Cambridge University Press.http:/ /dx.doi.org/10.1017/CBO9780 511733109

Cook, V. J. (1999). Teaching spelling. Retrieved May 17, 2015 from http://privatewww.essex.ac.uk/ vcook/ OBS2O.htm

Cook, V. (2001). Using the first language in the classroom. Canadian Modern Language Review, 57(3), 402-423 http://dx.doi.org/10.3138/cmlr.57.3.402

Diab, N. (1996) The transfer of Arabic in the English writings of Lebanese students. ESP 18(1) 71-83.

Ellis, R. (1997). Second Language Acquisition. Oxford: Oxford University Press.

Gass, S., and Selinker, L. (2008). Second language acquisition: an introductory course, Mahwah, NJ: LEA, Chapter 3.2. Retrieved on Oct 23, 2015 from http://ecaths1.s3.amazonaws.com/soleda dpampilloadquisicion/1865601592.Second Language-Acquisition.pdf

Harbord, J. (1992). The use of the mother tongue in the classroom. ELT Journal, 46(4), 350355. http://dx.doi.org/10.1093/elt/46.4.350

Ibrahim M (1983). The role of English Departments in Arab Universities, In Dihayat and Ibrahim (eds.), Papers from the First Conference on the Problems of Teaching English Language and Literature at Arab Universities, University of Jordan, Amman-Jordan.

Jie, X. (2008). Error theories and second language acquisition [Electronic version]. US-China foreign language, 6(1), 35-42.
Kharma, N. \& Hajjaj. (1989). Errors in English among Arabic speakers: Analysis and remedy. London: Longman

Macdonald, C. (1993). Using the target language. Cheltenham: Mary Glasgow.

Ministry of Education (1974). The educational policy in the Saudi Arabian kingdom. 2nd ed. Riyadh: Ministry of education.

Mukattash, L. (1983). The problem of difficulty in foreign language learning. In Dahiyat, E./Ibrahim, M. (eds.) Papers from the First Conference on the Problems of Teaching English Language and Literature at Arab Universities. Amman: University of Jordan.

O'Malley, J. and Chamot, A. (1990). Learning strategies in second language acquisition. Cambridge: Cambridge University Press. http:/ / dx.doi.org/10.1017/CBO978113952 4490

Sabbah, S. S. (2015). Negative transfer: Arabic language interference to learning English. Arab World English Journal, 6(4), 269-288.

Suleiman, S. (1983), Teaching English to Arab students at the university level. In Dihayat and Ibrahim (eds.), Papers from the First Conference on the Problems of Teaching English Language and Literature at Arab Universities. Amman: University of Jordan.

Swan, M. \& Smith, B. (Eds.) (1987). Learner English: A teacher's guide to interference and other problems. New York: Cambridge University Press.

Wallace, M. J. (1998). Action research for language teachers. Cambridge: Cambridge University Press.

Willis, D. and Willis, J. (2007). Doing task-based teaching. Oxford: Oxford University Press.

Zughoul, M. (1984). The Linguistic Attitudes of Arab University Students: Factorial Structure and Intervening Variables (In Arabic). J. the Jordanian Academy of Arabic, 25-26, 148-200. http://dx.doi.org/10.1515/ijsl.1984.50.155 